\title{
Spatial analysis of AIDS in the state of Maranhão: an ecological study 2011-2018
}

\author{
Análise espacial da aids no estado do Maranhão: um estudo ecológico 2011-2018 \\ Análisis espacial del sida en el estado de Maranhão: un estudio ecológico 2011-2018
}

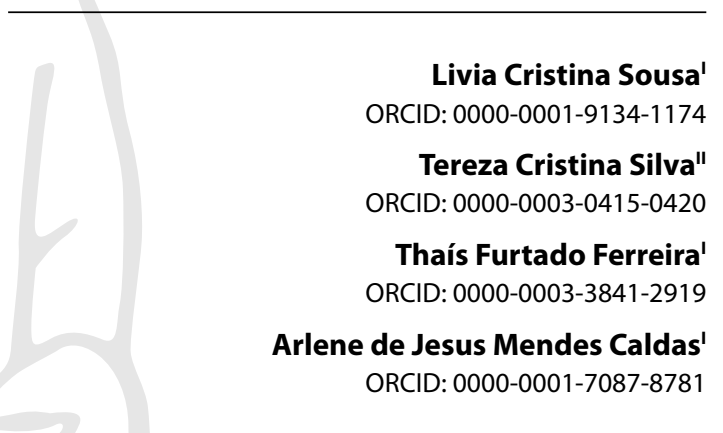

'Universidade Federal do Maranhão. São Luís, Maranhão, Brazil.

"Instituto Federal de Educação, Ciência e Tecnologia. São Luís, Maranhão, Brazil.

How to cite this article: Sousa LC, Silva TC, Ferreira TF, Caldas AJM. Spatial analysis of AIDS in the state of Maranhão: an ecological study 2011-2018. Rev Bras Enferm. 2022;75(1):e20210131. https://doi.org/10.1590/0034-7167-2021-0131

Corresponding author: Livia Cristina Sousa E-mail: livia4dotora@gmail.com

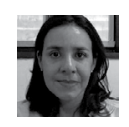

EDITOR IN CHIEF: Antonio José de Almeida Filho ASSOCIATE EDITOR: Ana Fátima Fernandes

Approval: 04-22-2021

\begin{abstract}
Objective: Analyze the spatio-temporal distribution of AIDS cases in Maranhão. Methods: Ecological study of AIDS cases in the Notifiable Diseases Information System, 2011-2018. Gross and adjusted incidences were calculated using the Baysean method; then, the Moran Global and Local Indices to observe the existence of spatial autocorrelation of the cases and for the delimitation of high and low risk clusters. Results: 6,349 cases were reported, which were distributed heterogeneously. There was an advance of cases to new areas and persistence in old areas, such as in the capital São Luís and its surroundings. The dissemination did not occur at random, with positive spatial autocorrelation, with evidence of the formation of clusters in the municipalities of São Luís, São José de Ribamar and Paço do Lumiar. Conclusion: High-risk areas have been identified and should be considered a priority for investment in health, management, and organization of health services.
\end{abstract}

Descriptors: Acquired Immunodeficiency Syndrome; Risk; Spatial Analysis; Epidemiology; Ecological Studies.

\section{RESUMO}

Objetivo: Analisar a distribuição espaço-temporal dos casos de aids no Maranhão. Métodos: Estudo ecológico dos casos de aids no Sistema de Informação de Agravos de Notificação, 2011-2018. Calcularam-se as incidências bruta e ajustada pelo método bayseano; em seguida, os Índices de Moran Global e Local para observar a existência de autocorrelação espacial dos casos e para delimitação de aglomerados de Alto e Baixo Risco. Resultados: Foram notificados 6.349 casos, que se distribuíram de forma heterogênea. Houve o avanço de casos para novas áreas e persistência nas áreas antigas, como na capital São Luís e seu entorno. A disseminação não ocorreu de forma aleatória, existindo autocorrelação espacial positiva, com evidência da formação de aglomerados nos municípios de São Luís, São José de Ribamar e Paço do Lumiar. Conclusão: Foram identificadas áreas de alto risco, devendo ser consideradas prioridade para o investimento em saúde, gestão e organização dos serviços de saúde.

Descritores: Síndrome da Imunodeficiência Adquirida; Risco; Análise Espacial; Epidemiologia; Estudos Ecológicos.

\section{RESUMEN}

Objetivo: Analizar la distribución espacio-temporal de los casos de SIDA en Maranhão. Métodos: Estudio ecológico de casos de SIDA en el Sistema de Información de Enfermedades de Notificación, 2011-2018. Las incidencias brutas y ajustadas se calcularon utilizando el método de Baysean; luego, los Índices de Moran Global y Local para observar la existencia de autocorrelación espacial de los casos y para la delimitación de aglomerados de Alto y Bajo Riesgo. Resultados: se notificaron 6.349 casos, los cuales se distribuyeron de forma heterogénea. Hubo un avance de casos a nuevas áreas y persistencia en áreas antiguas, como en la capital São Luís y sus alrededores. La diseminación no ocurrió al azar, con autocorrelación espacial positiva, con evidencia de la formación de aglomerados en los municipios de São Luís, São José de Ribamar y Paço do Lumiar. Conclusión: Se han identificado áreas de alto riesgo y deben considerarse una prioridad para la inversión en salud, gestión y organización de los servicios de salud. Descriptores: Síndrome de Inmunodeficiencia Adquirida; Riesgo; Análisis Espacial; Epidemiología; Estudios Ecológicos. 


\section{INTRODUCTION}

The acquired immunodeficiency syndrome is a relevant public health problem with a wide worldwide distribution ${ }^{(1-2)}$. Despite advances in responding to the AIDS epidemic, providing diagnosis and treatment to all people remains a challenge $\mathrm{e}^{(3)}$.

In recent years, AIDS cases have remained stable in Brazil(4), however they continue to increase in the state of Maranhão, where the detection rate increased from 12.6 in 2008 to $19.7 / 100$ thousand inhabitants in 2018, occupying the 11 th position in Brazil and the 2nd position in the Northeast Region ${ }^{(5)}$.

A study ${ }^{(6)}$ carried out on the spatial and temporal distribution of AIDS cases in Brazil, in the period 2008-2011, showed a non-uniform distribution in the Brazilian territory, highlighting an increased risk of transmission in the Northeast, during the studied period. In another study ${ }^{(7)}$, carried out in the state of Ceará, relating the spatial distribution of AIDS with socioeconomic determinants, it was demonstrated that different indicators between municipalities are reflected in a also different distribution, determining locations with few or no reported cases and locations with high disease rates where the socioeconomic conditions of the population are better.

In the search for understanding the distribution of diseases such as AIDS, the use of geoprocessing tools is important to produce, store, process, analyze and represent information related to public health, facilitating the understanding of the facts and phenomena that occur in the geographical space. Such instruments provide conditions for the mapping of diseases and risk assessment, contributing to the structuring, analysis of socioenvironmental risks and the planning of health actions ${ }^{(8)}$.

In this context, considering that the state of Maranhão has a large territorial extension, low Human Development Index and social, economic, and geographical disparities that can influence this distribution, it is justified to know the spatial and temporal distribution of AIDS cases in the state through the geographic information system, as this allows a better understanding of the dynamics of the disease. This information can be used by managers and health professionals for surveillance actions, since they identify the geographical areas of greatest epidemiological pressure and contribute to prevention strategies that directly impact the transmission chain, enabling the development of more effective intervention measures.

\section{OBJECTIVES}

To analyze the spatio-temporal distribution of AIDS cases in the state of Maranhão, from 2011 to 2018.

\section{METHODS}

\section{Ethical aspects}

The research was carried out with secondary data without identification of the participants, in compliance with the ethical aspects of Resolutions 466/2012 and 510/2016 of the National Health Council (CNS), with the submission to the Ethics Committee being waived.

\section{Study design, period, and location}

This is an ecological study of AIDS cases reported in the period 2011 to 2018, using the state's municipalities as the unit of analysis.

The survey was carried out in the state of Maranhão, located in the Northeast Region, with an area of $329,642 \mathrm{~km}^{2}$. According to the 2010 IBGE census, the state had 6,574,789 inhabitants, with the capital São Luís being the most populous city. Maranhão consists of 217 municipalities, 5 mesoregions and 21 geographic microregions, areas formed according to the physical, geographic, and productive structure of the state. The five mesoregions of Maranhão are divided into: North, East, Center, West and South ${ }^{(9)}$.

\section{Population; inclusion and exclusion criteria}

The study population comprised all AIDS cases reported in the Notifiable Diseases Information System (Sinan), from 2011 to 2018 , of residents in the state of Maranhão. There were 7,370 registered AIDS notifications for those over 13 years of age. Of these, 1,021 cases were discarded, 678 of which were non-residents in the state of Maranhão and 343 were duplicates. Thus, 6,349 AIDS cases over 13 years of age were eligible for the study. This age group was chosen because it is used in the definition of AIDS cases in adults by the Ministry of Health ${ }^{(10)}$ for the purpose of reporting cases.

Any individual with laboratory evidence, a symptom of a disease indicative of AIDS and/or CD4 + T lymphocyte count below $350 / \mathrm{mm} 3$, was considered as a case of AIDS, as well as death due to the exceptional criterion ${ }^{(10)}$.

The following were excluded: AIDS cases that did not present identification of the municipality of residence in the state of Maranhão (which would make spatialization unfeasible) or the identification was from another state; and duplicates with two or more records for the same case.

For the analysis of duplications, manual purifications were performed in order to quantify the records matched and belonging to the same individual. Duplication of registration was considered when the same patient was notified for AIDS more than once. After matching the cases, duplications were analyzed using the following criteria: patient's name, mother's name, and date of birth. In case of duplication, the oldest notification was kept, and the most recent notification was deleted from the database. In some cases, the oldest notification was supplemented with information from the most recent notification before the latter was deleted.

\section{Variables and data source}

Information related to AIDS cases was collected in September 2019, in the Sinan database, made available by the Epidemiological Surveillance service of the State Health Secretariat. For the descriptive analysis of the cases, the variables "year of notification" were used in Sinan. "And" municipality of residence ". To obtain population data from the municipalities of Maranhão, population estimates for each year, produced by the Brazilian Institute of Geography and Statistics (IBGE), available in the virtual environment of the SUS Department of Health (DATASUS), were used ${ }^{(11)}$. 


\section{Study protocol}

The guidelines of the Strengthening the Reporting of Observational Studies in Epidemiology (STROBE) initiative were followed to organize the methodological design of the study ${ }^{(12)}$.

\section{Analysis of results and statistics}

Initially, gross incidences were calculated and adjusted by the Bayesian method in order to minimize fluctuations due to the small number of cases and population in some municipalities. With the Bayesian method, a weighted average was obtained between the gross incidence of the municipality and the incidence of the nearest neighbors ${ }^{(13)}$.

For the calculation of incidences, AIDS cases that occurred in the municipality were considered as a numerator; and as a denominator, the resident population in the respective municipality, multiplied by 100 thousand.

The spatial analysis of the data started with the creation of the neighborhood matrix between the 217 municipalities in the state of Maranhão, with the objective of comparing the similarity of the geographical attributes in neighboring features. As this is an area analysis study, we adopted the first-order Queen neighborhood matrix, as it was the one that captured the maximum spatial dependence, that is, the one that generated the highest value of the Moran Index Significant overall(14). The created neighborhood matrix presented an average of 5.46 ( $\pm 1-13)$ neighbors per municipality.

To observe the existence of spatial autocorrelation, the Moran Global Index (I) was calculated. Then, the Local Moran Index (li) was calculated to define the high and low risk AIDS clusters. For this purpose, the average AIDS incidence in the 217 municipalities, adjusted by the local empirical Bayesian method, was considered as the cutoff point. For both I and li, $p$ value less than 0.05 was taken into account as statistical significance.

It was considered as a cluster of High Risk the group of those municipalities that had an above-average incidence and were surrounded by municipalities that also had high incidences (autocorrelation pattern called Alto-Alto). Conversely, it was considered as a cluster of Low Risk the set of those municipalities that showed incidence below the average and were surrounded by municipalities that also showed low incidences (low-low autocorrelation pattern) ${ }^{(14)}$.
All statistical analysis of the present study was performed using GeoDa software, version 1.14.0 (Spatial Analysis Laboratory, University of Illinois at Urbana-Champaign, USA). Choropleth maps were built using the QGIS 3.6.2 software (Quantum Geographic Information System) to present the data. The digital cartographic network of the municipalities was acquired from the Brazilian Institute of Geography and Statistics (IBGE).

\section{RESULTS}

During the period from 2011 to 2018, 6,349 AIDS cases were notified in the state of Maranhão (with an annual average of 793 cases), which were distributed in a heterogeneous way in all the five mesoregions of the state and did not occur at random, positive spatial autocorrelation (Figure 1).
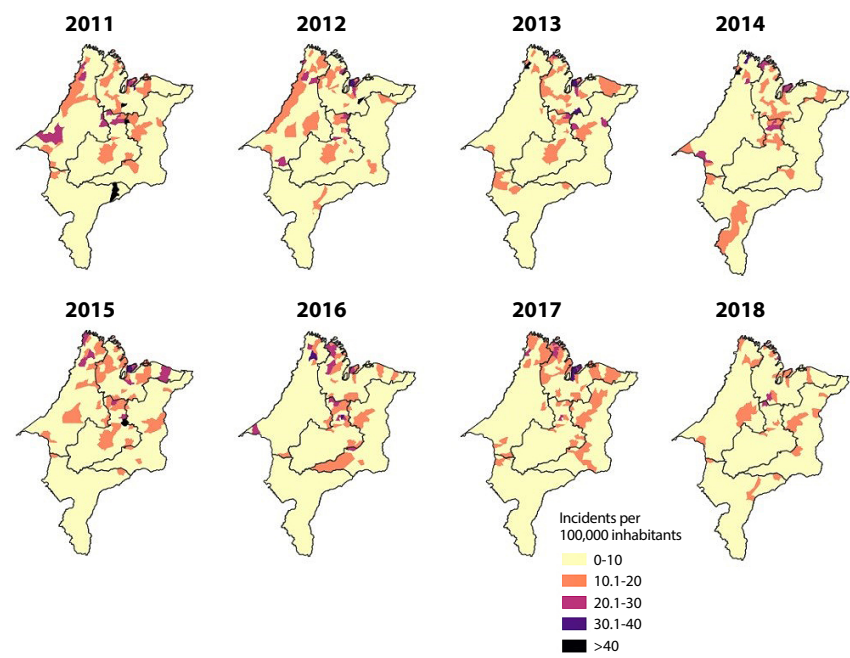

Figure 1 - Gross incidence of AIDS cases in the state of Maranhão, Brazil, in the period 2011-2018

There was variation in the gross incidence of AIDS over the years of the study, with 2015 having the highest incidence $(6.73$ \pm 8.14 cases per 100 thousand inhabitants) and 2018 , the lowest incidence $(4.52 \pm 6.00$ cases per 100 thousand inhabitants) (Table 1).

After adjusting the data by the Bayesian method, it is observed that AIDS cases maintained their distribution in a heterogeneous manner and positive spatial autocorrelation (Figure 2).

Table 1 - Incidence and clusters of AIDS cases in the state of Maranhão, Brazil, in the period 2011-2018

\begin{tabular}{|c|c|c|c|c|c|c|c|c|}
\hline Variables/Year & 2011 & 2012 & 2013 & 2014 & 2015 & 2016 & 2017 & 2018 \\
\hline Average annual incidence* & $\begin{array}{c}5.64 \\
\mathrm{DP}=8.76\end{array}$ & $\begin{array}{c}5.79 \\
\mathrm{DP}=7.73\end{array}$ & $\begin{array}{c}6.23 \\
\mathrm{DP}=8.56\end{array}$ & $\begin{array}{c}6.41 \\
\mathrm{DP}=8.69\end{array}$ & $\begin{array}{c}6.73 \\
\mathrm{DP}=8.14\end{array}$ & $\begin{array}{c}6.62 \\
\mathrm{DP}=8.71\end{array}$ & $\begin{array}{c}6.67 \\
\mathrm{DP}=7.83\end{array}$ & $\begin{array}{c}4.52 \\
D P=6.00\end{array}$ \\
\hline Adjusted mean incidence* & $\begin{array}{c}7.88 \\
\mathrm{DP}=6.63\end{array}$ & $\begin{array}{c}7.67 \\
\mathrm{DP}=6.03\end{array}$ & $\begin{array}{c}7.96 \\
D P=6.87\end{array}$ & $\begin{array}{c}8.11 \\
D P=6.26\end{array}$ & $\begin{array}{c}8.71 \\
D P=6.33\end{array}$ & $\begin{array}{c}8.04 \\
D P=5.84\end{array}$ & $\begin{array}{c}8.07 \\
\mathrm{DP}=6.00\end{array}$ & $\begin{array}{c}5.71 \\
\mathrm{DP}=4.13\end{array}$ \\
\hline Global Moran Index ${ }^{* *}$ & 0.49 & 0.64 & 0.64 & 0.61 & 0.67 & 0.68 & 0.72 & 0.60 \\
\hline $\begin{array}{l}\text { High-High Agglomerate } \\
\text { Incidence in the cluster* } \\
\text { Number of municipalities involved }\end{array}$ & $\begin{array}{c}19.89 \\
25\end{array}$ & $\begin{array}{c}20.10 \\
19\end{array}$ & $\begin{array}{c}19.81 \\
25\end{array}$ & $\begin{array}{c}21.63 \\
20\end{array}$ & $\begin{array}{c}21.56 \\
22\end{array}$ & $\begin{array}{c}18.72 \\
30\end{array}$ & $\begin{array}{c}21.99 \\
19\end{array}$ & $\begin{array}{c}13.39 \\
20\end{array}$ \\
\hline $\begin{array}{l}\text { Low-Low Chipboard } \\
\text { Incidence in the cluster* } \\
\text { Number of municipalities involved }\end{array}$ & $\begin{array}{c}1.93 \\
41\end{array}$ & $\begin{array}{c}2.91 \\
38\end{array}$ & $\begin{array}{c}1.96 \\
42\end{array}$ & $\begin{array}{c}2.27 \\
42\end{array}$ & $\begin{array}{c}2.47 \\
38\end{array}$ & $\begin{array}{c}2.90 \\
50\end{array}$ & $\begin{array}{c}3.03 \\
41\end{array}$ & $\begin{array}{c}2.33 \\
29\end{array}$ \\
\hline
\end{tabular}

${ }^{*}$ Average incidence/100 thousand inhabitants adjusted by the local empirical Bayesian method. ${ }^{* *} p \leq 0.05$ 

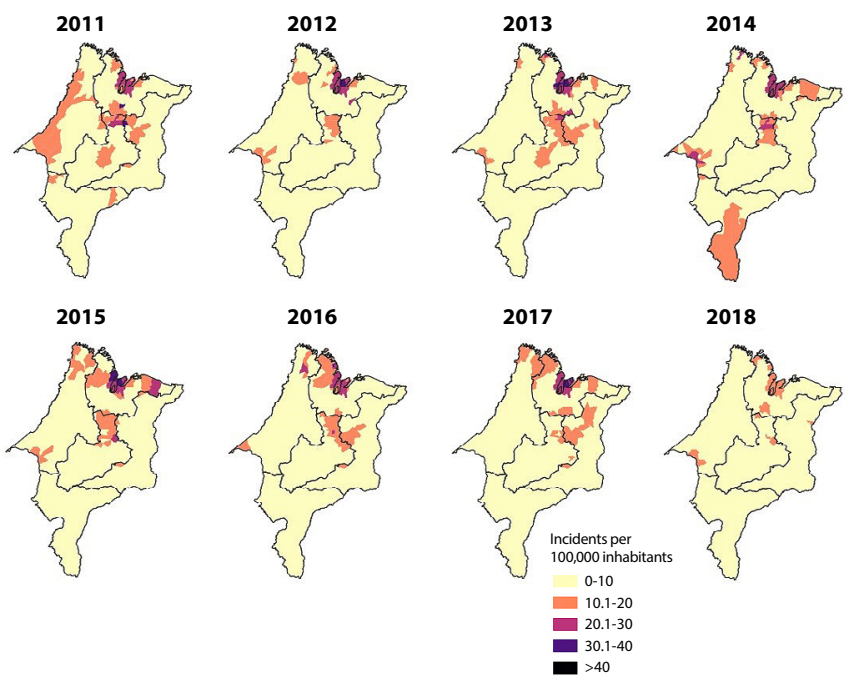

Figure 2 - Adjusted incidence (Bayesian method) of AIDS cases in the state of Maranhão, Brazil, in the period 2011-2018

There was a better smoothing of the data: the adjusted incidence also changed in the period, reaching a higher incidence in 2015 (8.71 \pm SD 6.33 cases per 100 thousand inhabitants) and in 2018 a lower incidence $(5.71 \pm$ SD 4.13 cases per 100 thousand inhabitants) (Figure 2, Table 1).

In the spatial statistical analysis, statistically significant clusters of High and Low Risk were identified (Figure 3). The High-Risk areas maintained a distribution pattern in the surveyed period, with a concentration in municipalities located in the northern and central mesoregions of the state of Maranhão.

The cluster of High Risk of illness for AIDS located in the northern mesoregion was formed by the grouping of the municipalities of Alcântara, Arari, Axixá, Apicum Açu, Bacabeira, Bacuri, Bacurituba, Bequimão, Cajapió, Conceição do Lago Açú, Cedral, Central do Maranhão, Cururupu, Guimarães, Icatú, Matões do Norte, Mirinzal, Paço do Lumiar, Peri Mirim, Pinheiro, Puerto Rico do Maranhão, Presidente Juscelino, Raposa, Rosário, Santa Rita, São Bento, São José de Ribamar, São Luís and Serrano do Maranhão. In the central mesoregion, it was formed by the grouping of the municipalities of Bacabal, Igarapé Grande, Lago Verde, Lima Campos, Olho D'água das Cunhãs, Pio XII, Pedreiras, Santo Antônio dos Lopes, São Luiz Gonzaga do Maranhão, São Mateus do Maranhão and Trizidella Valley.

The Low-Risk areas were mainly concentrated in the eastern and southern mesoregions. There was a variation in cases in the western mesoregion with expansion in the years 2013 and 2014, reduction in the year 2015 and again ascendancy in the years 2016 to 2018 . In 2018, the data showed a reduction in the southern mesoregion, making this area to be considered nonsignificant for AIDS.

The Low Risk cluster of illnesses for AIDS located in the eastern mesoregion was formed by the grouping of the municipalities of Araioses, Anapurus, Água Doce do Maranhão, Barão de Grajaú, Brejo, Buriti, Buriti Bravo, Belágua, Chapadinha, Coelho Neto, Duque Bacelar, Lagoa do Mato, Magalhães de Almeida, Mata Roma, Matões, Miracles of Maranhão, Mirador, New York, Paraibano, Parnarama, Passage Franca, Pastos Bons, São Benedito do
Rio Preto, Santa Quitéria do Maranhão, Santana do Maranhão, São Bernardo, São Francisco do Maranhão, São João dos Patos, Sucupira do Riachão and Urbano Santos. In the southern mesoregion, the Low Risk cluster was formed by the municipalities of Alto do Parnaíba, Balsas, Benedito Leite, Carolina, Feira Nova do Maranhão, Fortaleza dos Nogueiras, Loreto, Nova Colina, Riachão, São Pedro dos Crentes, São Raimundo das Mangabeiras, São Félix do Balsas, São Pedro dos Crentes, Sambaíba, Tasso Fragoso.
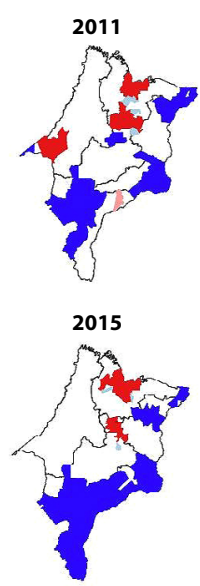

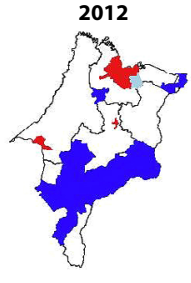

2016

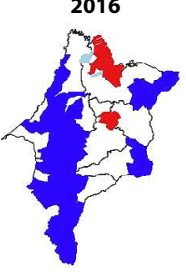

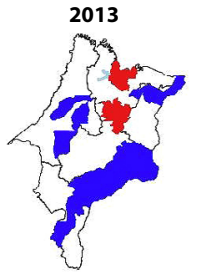

2017

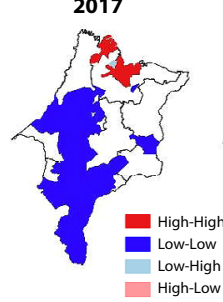

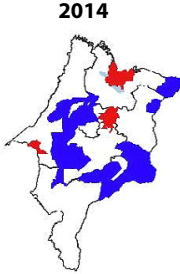

2018

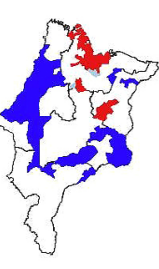

Figure 3 - Clusters of AIDS cases in the state of Maranhão, Brazil, in the period 2011-2018

\section{DISCUSSION}

The present study demonstrates that there was a heterogeneous geographical distribution of AIDS cases in the state of Maranhão, in the period from 2011 to 2018 , which can be attributed to the process of internalization of the AIDS epidemic, indicating a spread to medium and small municipalities where the least-assisted communities are found, as was also demonstrated in studies carried out in the states of Alagoas ${ }^{(15)}$ and Piauí(16).

It became evident that there was a gradual increase in the incidence rate of AIDS cases in the period from 2011 to 2015 and a reduction in the incidence in the period from 2016 to 2018. These data are in line with the Ministry of Health's Panel of Epidemiological Indicators on HIV/AIDS, which showed an oscillation year by year, with an increase in the disease in the state of Maranhão between the years 2009 to 2017 and a reduction in the incidence rate since $2018^{(17)}$. The growth can be attributed to the process of expanding the testing, which produces more notification of cases; the subsequent decline may occur due to the influence of public policies for the control of HIV in the state, such as better infrastructure and organization of specialized services that provide care, which may have contributed to the identification of new cases.

Another aspect found in this study was the advancement of cases to new areas and the persistence of old areas of occurrence of the disease, as in the capital São Luís and its surroundings. The spread of AIDS cases did not occur at random, with positive spatial autocorrelation, indicating that nearby regions are similar to each other and evidencing the formation of high-risk clusters in the municipalities of São Luís, São José de Ribamar and Paço do Lumiar. These three municipalities are in the ranking of the 
hundred cities in Brazil with the highest rates of detection of AIDS cases $^{(5)}$.

AIDS cases in the state of Maranhão were mainly concentrated in the northern mesoregion throughout the study period. This situation can be explained by the fact that this mesoregion is a coastal area, with a large population size, political and economic center of the state, an area of tourist potential, of great social and economic vulnerability ${ }^{(9,18)}$ and where the São Luís metropolitan region is located.

Studies carried out in Brazil $^{(6,19)}$ and in the state of Ceará(7) showed a higher concentration of AIDS cases in coastal areas, in urban centers with a greater sociodemographic and socioeconomic flow, being corroborated by this study. The cases tend to be concentrated in the areas with the highest population density, and one reason is the intense migration of people in search of health care in the most urbanized areas where the large specialized treatment centers are concentrated ${ }^{(20)}$. In addition, on the northeastern coast, there are tourist routes and/or highways, which determines a greater number of people susceptible to spreading the HIV virus through prostitution and drug trafficking ${ }^{(15)}$, resulting from the situation of poverty and of social exclusion ${ }^{(21)}$.

Socioeconomic inequalities, such as those existing in the state of Maranhão(9), influence the dynamics of AIDS ${ }^{(7)}$. A study conducted in the state of Piauí pointed out that the illiteracy rate was shown to be a risk factor for AIDS deaths ${ }^{(16)}$. Another survey conducted in the Northeast showed an increase in AIDS cases in the population with less education ${ }^{(22)}$. Dissemination in the poorest layers and with a low level of education indicates greater susceptibility, possibly due to the lack of information and less access to health services, means of prevention and treatment ${ }^{(22-25)}$.

However, research conducted in Ceará has shown that AIDS is associated more with the pace and risky behavior of modern and urban life than with factors related to poverty ${ }^{(7)}$. Behavioral and cultural factors such as the use of alcohol and other drugs, unprotected sexual practices, multiple partners, issues of sexuality, gender and stigmas increase vulnerability to HIV(24-26), which may also explain the increased incidence of infection, justifying the importance of intensifying health promotion and disease prevention actions both in the general population and in the key population, the most affected by the epidemic.

In this sense, it is imperative that disease prevention actions should also consider the specificity of each territory, with actions to combat stigma and prejudice being one of the challenges for facing AIDS. Although the state of Maranhão has decentralized HIV testing to all municipalities, this offer is still low. In addition, the services provided with the best infrastructure are concentrated in the capital, São Luís, which can be a factor that makes it difficult for sick individuals from their home municipality to seek anonymity/diagnostic secrecy and better treatment opportunities. A study carried out in Minas Gerais ${ }^{(27)}$ found that the approach of the health team with the user about AIDS as a chronic disease can help in reducing the stigma, stimulating the gradual increase in HIV testing.

It is important to highlight that the High Risk cluster in the northern mesoregion, which includes the capital São Luís, has a low coverage of the Family Health Strategy $(\mathrm{FHS})^{(28)}$, indicating that the large portion of the population in this location has a deficit of assistance, with low response capacity regarding health promotion actions, disease prevention, diagnosis and treatment, which are part of the FHS guidelines ${ }^{(29-30)}$.

A survey carried out in Brazil found that the coverage of Primary Care remains relatively low in some regions of Brazil, even though there is more investment to change the predominant care model. The constant turnover of professionals, the discontinuity of actions and the disconnection between the epidemiological reality and the programs developed are aspects that can interfere in reaching this level of care in preventive and assistance actions directed at the control of AIDS. The aforementioned research also highlights the need to improve the intervention model, giving greater weight to preventive actions, without prejudice to the activities of assistance and treatment to the health of people with HIV/AIDS ${ }^{(31)}$.

In the present study, it is emphasized that the locations where the Low Risk clusters are located in the Eastern and Southern mesoregions also presented municipalities with intense social and economic vulnerabilities ${ }^{(9)}$. However, they have municipalities with greater population coverage of family health teams ${ }^{(28)}$, and this must be a protective factor for a lower risk of illness due to AIDS, because the greater the coverage, the better strategies for promoting health are expected health, disease prevention and lower rate of illness ${ }^{(7)}$.

However, the existing data on AIDS is not sufficient to affirm that the health promotion and disease prevention actions developed in these locations are adequate for control as a public health problem. A study ${ }^{(29)}$ carried out in the state of Maranhão points out that the expansion in quantitative terms of the coverage of Primary Care does not mean guaranteeing comprehensive health care or that it is satisfactorily in accordance with what is recommended, thus improving the quality of life of the population. population. For this to happen, it is essential to reflect on the operationalization, sustainability and quality of the services provided.

Since AIDS is causally related to different contexts (social, behavioral, and structural), it can have a different impact on the same geographical space due to poor living conditions, such as low income, low education, promiscuity and other risky behaviors. it is necessary to carry out new and continuous studies to better understand the dynamics of AIDS in the population.

\section{Study limitations}

There is a possibility that the data may be underestimated due to the underreporting of AIDS cases in the Notifiable Diseases Information System.

\section{Contributions to the area of Nursing, Health or Public Policies}

This research highlights the contributions of the geoprocessing tool for epidemiological studies and improvement of the nursing management process, providing an expanded view of the situation of a specific disease or condition in space, in order to provide an explanatory chain of the problems of the territory as well as guide decision-making and improvement of public health policies. 


\section{CONCLUSION}

AIDS cases in the state of Maranhão showed heterogeneous spatial distribution in the different mesoregions. Although there has been a slight decline in the incidence rate since 2016, it is still evident that there is a concentration of AIDS cases in the HighRisk clusters in the North and Center mesoregions, indicating a deficit in health care in these locations.

The study made it possible to identify priority areas for investments in health, highlighting important places to be considered in terms of the management and organization of health services in order to ensure equity and integrality in the care of populations living with HIV/AIDS.

\section{SUPPLEMENTARY MATERIAL}

Master's dissertation "The aids epidemic in the state of Maranhão: space-time analysis", available from: https://renasffiocruz.br/sites/renasf.fiocruz.br/files/disseracoes/2019_UFMA_ Disserta\%C3\%A7\%C3\%A30_L\%C3\%ADvia\%20Cristina\%20Sousa.pdf

\section{REFERENCES}

1. Levi J, Raymond A, Pozniak A, Vernazza P, Kohler P, Hill A. Can the UNAIDS 90-90-90 target be achieved? a systematic analysis of national HIV treatment cascades. BMJ Global Health. 2016;(1):e000010. https://doi.org/10.1136/bmjgh-2015-000010

2. Organização Pan Americana de Saúde (OPAS). Folha informativa HIV/aids[Internet]. Brasília: Organização Pan Americana de Saúde; 2017 [cited 2018 Jun 10]. Available from: https://www.paho.org/bra/index.php?option=com_content\&view=article\&id=5666:folha-informativa-hiv-aids\&ltemid=812

3. United Nations (UM). Joint United Nations Programme on HIV/AIDS (UNAIDS). 90-90-90. An ambitious treatment target to help end the aids epidemic[Internet] Geneva: UNAIDS; 2014.[cited 2020 jun 2]. Available from: https://www.researchgate.net/publication/323198409_ Know_Your_Epidemic_Strengthen_Your_ResponseDeveloping_a_New_HIV_Surveillance_Architecture_to_Guide_HIV_Resource_ Allocation_and_Target_Decisions/fulltext/5a858d32458515b8af87c71c/Know-Your-Epidemic-Strengthen-Your-Response-Developing-aNew-HIV-Surveillance-Architecture-to-Guide-HIV-Resource-Allocation-and-Target-Decisions.pdf

4. Alves ATJ, Nobre FF, Waller LA. Exploring spatial patterns in the associations between local aids incidence and socioeconomic and demographic variables in the State of Rio de Janeiro, Brazil. Spatial Spatio-Temp Epidemiol. 2016;(17):85-93.https://doi.org/10.1016/j.sste.2016.04.008

5. Ministério da Saúde (BR). Secretaria de Vigilância em Saúde. Departamento das IST, do HIV/aids e das hepatites virais. Bol Epidemiol HIV/ Aids[Internet]. 2019 [cited 2019 Dec 10]. Available from: http://www.aids.gov.br/pt-br/pub/2019/boletim-epidemiologico-de-hivaids-2019

6. Sousa AIA, Pinto Jr VL. Spatial and temporal analysis of aids cases in Brasil, 1996-2011: increased risk áreas over time. Epidemiol Serv Saude. 2016;25(3). https://doi.org/10.5123/s1679-49742016000300003

7. Paiva SS, Pedrosa NL, Galvão MTG. Spatial analysis of aids and the social determinants of health. Rev Bras Epidemiol. 2019;22:e190032. https://doi.org/10.1590/1980-549720190032

8. Chiaravalloti-Neto F. O geoprocessamento e saúde pública. Arq Ciênc Saúde. 2017;23(4):1-2. https://doi. org/10.17696/2318-3691.23.4.2016.661

9. Instituto Brasileiro de Geografia e Estatística (IBGE). Censo demográfico 2010[Internet]. Brasília(DF): IBGE; 2010[cited 2019 Dec 4]. Available from: https://censo2010.ibge.gov.br/

10. Ministério da Saúde(BR). Secretaria de Vigilância em Saúde. Coordenação Geral de desenvolvimento da Epidemiologia em Saúde. Guia de Vigilância em Saúde: volume único. 3 ed. Brasilia: MS; 2019. 739 p.

11. Ministério da Saúde(BR). Departamento de Informática do Sistema Único de Saúde. Informações de Saúde(Tabnet). Demográficas e socioeconômicas[Internet]. Brasília(DF): Ministério da Saúde; 2019[cited 2019 Dec 4]. Available from: http://www2.datasus.gov.br/DATASUS/ index.php?area $=0206$

12. Malta M, Cardoso LO, Bastos FI, Magnanini MMF, Silva CMFP. STROBE initiative: guidelines on reporting observational studies. Rev Saúde Públ [Internet]. 2010[cited 10 Feb 2020];44(3):1-5. Available from: https://www.scielo.br/pdf/rsp/v44n3/en_21.pdf

13. Bailey TC, Gatrell AC. Interactive spatial data analysis. Essex: Longman; 1995. 432p.

14. Câmara G, Carvalho MS, Cruz OG, Correa V. Análise espacial de áreas. In: Druck S, Carvalho MS, Câmara G, Monteiro AVM. (Eds). Análise Espacial de Dados Geográficos[Internet]. Brasília: Embrapa; 2004[cited 2020 Jun 4]. Available from: http://www.dpi.inpe.br/gilberto/livro/ analise/cap5-areas.pdf

15. Santos CO, Silva LS, França AMB, Rodrigues APRA, Miyazawa AP. Perfil epidemiológico de casos de mulheres com sida no Estado de Alagoas no período de 2009 a 2014. Ciênc Biol Saúde[Internet]. 2015[cited 2020 Jun 17];43(1):77-92. Available from: https://periodicos.set.edu.br/ index.php/fitsbiosaude/article/view/2509/1500

16. Maranhão TA, Alencar CH, Magalhães MAFM, Sousa GJB, Ribeiro LM, Abreu WC, et al. Mortalidade pela síndrome da imunodeficiência adquirida e fatores sociais associados: uma análise espacial. Rev Bras Enferm. 2020;73(Suppl 5):e20200002. https://doi.org/10.1590/0034-7167-2020-0002 e20200002

17. Ministério da Saúde(BR). Departamento de Doenças de Condições Crônicas e Infecções Sexualmente Transmissíveis. Painel de Indicadores Epidemiológico da aids[Internet]. Brasília(DF): Ministério da Saúde; 2020 [cited 2020 Dec 10]. Available from: http://www.aids.gov.br/pt-br/ gestores/painel-de-indicadores-epidemiologicos 
18. Masullo YAG, Lopes JAV. Indicadores Econômicos da Região Metropolitana da Grande São Luís. Geogr Ensino Pesqui. 2017;21(1):30-40. https://doi.org/10.5902/2236499421050

19. Rodrigues-Jr AL, Ruffino-Netto A, Castilho EA. Spatial distribution of the human development index, HIV infection and AIDS-Tuberculosis comorbidity: Brazil, 1982-2007. Rev Bras Epidemiol. 2014;204-15. https://doi.org/10.1590/1809-4503201400060017

20. Kuchenbecker R, Grangeiro A, Veras MA. Global targets, local epidemics: the ultimate challenge for aids in Brazil? Rev Bras Epidemiol. 2015;18(Suppl-1):5-6. https://doi.org/10.1590/1809-4503201500050002

21. Leal CBM, Souza DA, Rios MA. Aspectos de vida e saúde das profissionais do sexo. Rev Enferm UFPE. 2017;11(11):4483-91. https://doi. org/10.5205/reuol.23542-49901-1-ED.1111201726

22. Silva CM, Alves RS, Santos TS, Bragagnollo GR, Tavares CM, Santos AAP. Epidemiological overview of HIV/AIDS in pregnant women from a state of northeastern Brazil. Rev Bras Enferm. 2018;71(suppl 1):568-76.https://doi.org/10.1590/0034-7167-2017-0495

23. Castillo-Arcos LC, Alvarez-Aguirre A, Bañuelos Barrera Y, Valle-Solís M O, Valdez-Montero C, Kantún-Marín MAJ. Age, Gender and Resilience in Sexual Risk Behavior of STI among adolescents in Southern Mexico. Enferm Glob. 2017;45:178-87. https://doi.org/10.6018/ eglobal.16.1.234921

24. Reis RK, Melo ES, Gir E. Factors associated with inconsistent condom use among people living with HIV/Aids. Rev Bras Enferm. 2016;69(1):406. https://doi.org/10.1590/0034-7167.2016690106i

25. Amaral RS, Carvalho STRF, Silva FMAM, Dias RS. Soropositividade para o HIV/aids e Características Sóciocomportamentais em Adolescentes e Adultos Jovens. Rev Pesq Saúde[Internet]. 2017[cited 2020 Jun 2];18(2):108-13. Available from: www.periodicoseletronicos.ufma.br/index. php/revistahuufma/article/view/8384/5209

26. Patrício ACFA, Bezerra VP, Nogueira JA, Moreira MASP, Camargo BV, Santos JS. Knowledge of sex workers about HIV/AIDS and its influence on sexual practices. Rev Bras Enferm. 2019;72(5):1311-7. https://doi.org/10.1590/0034-7167-2018-0590

27. Castro SS, Scatena LM, Miranzi A, Miranzi Neto A, Nunes AA. Temporal trend of HIV/aids cases in the State of Minas Gerais, $2007-2016$. Epidemiol Serv Saude. 2020;29(1):e2018387. https://doi.org/10.5123/S1679-49742020000100016

28. Ministério da Saúde (BR). Informação e Gestão da Atenção Básica. Relatórios Públicos dos Sistemas de Atenção Básica. Histórico de Cobertura Atenção Básica e-gestor AB[Internet]. Brasília(DF): Ministério da Saúde; 2019[cited 2019 Dec 13]. Available from: https:// egestorab.saude.gov.br/

29. Coimbra LC, Soeiro VMS, Amorim SMC. Análise da evolução da cobertura das estratégias de atenção básica no Estado. In: Indicadores da atenção básica no Maranhão. São Luís: EDUFMA, 2017.227p.

30. Melo EA, Maksud I, Agostini R. Cuidado, HIV/Aids e atenção primária no Brasil: desafio para a atenção no Sistema Único de Saúde? Rev Panam Salud Publica. 2018;42:e151. https://doi.org/10.26633/RPSP.2018.151

31. Grangeiro A, Escuder MML, Castilho EA. A epidemia de aids no Brasil e as desigualdades regionais e de oferta de serviço. Cad Saúde Pública. 2010;26(12):2355-67. https://doi.org/10.1590/S0102-311X2010001200014 